\title{
Omalizumabo efektyvumas gydant sunkią astmą: klinikinis atvejis
}

\author{
Laura Tamašauskienè, Diana Barkauskienė, Brigita Šitkauskienẻ \\ LSMU MA Pulmonologijos ir imunologijos klinika
}

Reikšminiai žodžiai: astma, omalizumabas, anti-lgE.

Santrauka. Omalizumabas - monokloninis antikūnas prieš imunoglobuliną E, skiriamas sunkia persistuojančia alergine astma sergantiems pacientams, kuriems simptomai dažnai kartojasi dieną ar pažadina nakti, kuriems buvo daug dokumentuotų sunkių astmos paūmẻjimu, nepaisant kasdien vartojamų didelių inhaliuojamujų gliukokortikoidų ir ilgai veikiančių beta 2 agonistų dozių. Omalizumabas pagerina astmos kontrolę, sumažina šios ligos paūmejjimų skaičį̣ ir gliukokortikoidų poreikį. Moksliniai tyrimai rodo, kad šis vaistas efektyvus gydant lètine idiopatine dilgèline sergančius asmenis, kurių reakcija i gydymą H1 antihistamininiais preparatais yra nepakankama. Straipsnio tikslas - apžvelgti omalizumabo efektyvumą gydant sunkią astmą bei pristatyti klinikinį atveji.

\section{IVADAS}

Astma yra lètiné kvẻpavimo taku uždegimo liga, pasireiškianti pasikartojančiais padidejjusio bronchų reaktyvumo ir kintančios bronchų obstrukcijos simptomais $[1,2]$. Dabar skiriamos trys astmos eigos sunkumo kategorijos: lengva, vidutinio sunkumo ir sunki [1]. Sunki astma diagnozuojama, kai liga kontroliuojama arba jos kontroliuoti nepavyksta taikant ketvirtos ar penktos pakopos gydymą [1]. Kadangi dažnai gydymas gali būti neveiksmingas dèl blogos ikvėpimo technikos, netinkamai vartojamu vaistų, gretutinių ligų, nuolatinio astmą provokuojančiu veiksnių poveikio, būtina atmesti šias aplinkybes ir tik tada galima teigti, kad astmos eiga yra sunki [1]. Tokiais atvejais, kai didelès inhaliuojamụjų gliukokortikoidu dozès ir ilgai veikiančiu beta 2 agonistu nèra veiksmingos, pacientui papildomai skiriama omalizumabo $[1,2]$. Šis vaistas yra monokloninis antikūnas prieš imunoglobuliną (Ig) E [3]. Moksliniai tyrimai rodo, kad omalizumabas efektyvus ir gydant lètinę idiopatinę dilgèlinę. Yra duomenu apie šio vaisto poveiki gydant atopini dermatitą, maisto alergiją bei kitas alergines li- gas. Tinkamai ịvertinti omalizumabo potencialą gydant ịvairias alergines ir nealergines ligas reikalingi išsamesni didesnés apimties tyrimai [4]. Straipsnio tikslas - apžvelgti omalizumabo efektyvuma gydant sunkią astmą bei pristatyti klinikini atveji.

\section{OMALIZUMABO EFEKTYVUMAS GYDANT SUNKIĄ ASTMĄ}

Omalizumabas selektyviai prisijungia prie žmogaus IgE ir neleidžia jam prisijungti prie receptorių, esančių ant putliụjų ląstelių ir bazofilu $[3,5]$. Taip slopinama šiuc ląsteliuc degranuliacija ir sumažèja uždegimo mediatorių išsiskyrimas. Omalizumabo leidžiama po oda. Šis vaistas metabolizuojamas kepenyse, jo vidutinis serumo pusinès eliminacijos laikas yra 26 dienos [3].

Moksliniai tyrimai rodo, kad omalizumabas yra efektyvus gydant sunkią, inhaliuojamiesiems gliukokortikoidams atsparią astmą. $2015 \mathrm{~m}$. pristatyti tyrimo, kurio metu stebèti vyresni nei $12 \mathrm{~m}$. vidutinio sunkumo ir sunkia astma sergantys pacientai, gydyti omalizumabu, rezultatai [6]. Vaisto efektyvumas buvo analizuotas po 6 ir 60 men. pagal astmos kontrolès testo rezultatus bei klausimyną, kuris vertina kasdienio aktyvumo ribotumą (darbo, mokyklos, laisvalaikio) dèl astmos. Pradejus gydymą, omalizumabo grupeje po 6 mèn. gerai kontroliuojamos astmos skaičius padidejo nuo buvusio pradinio 25 proc. iki 51 proc. ir iki 60 proc. praejjus 60 mèn. [6]. Pacientu, gydytu šiuo vaistu, kasdieninis aktyvumas taip pat pagerejo [6]. Portugalijoje atlikto perspektyvinio tyrimo duomenimis, omalizumabu gydytiems pacientams 41 proc. sumažejo suminé geriamụju gliukokortikoidu dozé [7]. Be to, tik $1 / 3$ pacientu, gydytu omalizumabu, per 12 mèn. laikotarpi prireikè skubios pagalbos dèl astmos paūméjimo [7]. J. Saji ir bendr. nustaté, kad gydytu omalizumabu asmenu grupeje pagerèjo astmos kontrolès testo ir astmos sveikatos klausimyno rezultatai, sumažèjo skubaus gydymo dèl astmos paūmejjimo poreikis bei suminè metilprednizolono dozè, tačiau plaučiu funkcija reikšmingai nepakito [8]. Priešingai, J. O. Steiss ir bendr. bei T. Tajiri ir bendr. tyrimai rodo, kad omalizumabas reikšmingai pagerino ir pacientụ plaučiu funkcijos rodiklius, ir astmos kontrolés testo rezultatus [9, 10]. Apibendrinant galima teigti, kad omalizumabo vartojimas sergant sunkia astma reikšmingai pagerina astmos kontrolę.

\section{KLINIKINIS ATVEJIS}

2014 m. Lietuvos sveikatos mokslų universiteto ligoninès (LSMUL) Kauno kliniku Pulmonologijos ir imunologijos klinikoje konsultuota $41 \mathrm{~m}$. pacientè J. K., kuri nuo vaikystès serga alergine astma ir alerginiu rinitu. Jai nustatytas įsijautrinimas žoliu žiedadulkių alergenams ir penicilino grupès antibiotikams. Pacientė skundėsi suintensyvejusiu dusuliu, ypač stipriu net ir nedidelio fizinio krūvio metu, be to, pastaruo- sius dvejus metus ji kasmet sirgo plaučiu uždegimu, astmos paūmèjimai vargindavo kelis kartus per metus, ji kasdien papildomai vartodavo trumpai veikiančių beta 2 agonistų. İvertinus tai, kad, nepaisant maksimalių 
1 lentelè. Pacientès J. K. plaučiu funkcijos pokyčiai po gydymo omalizumabu

\begin{tabular}{cccc}
\hline Data & FEV $_{1}$ & FVC & FEV $_{1} /$ VC \\
\hline $2014-04-08$ & $0,671,20$ proc. & $1,631,40$ proc. & 321,40 proc. \\
\hline $2014-12-19$ & $0,691,20$ proc. & $1,761,44$ proc. & 371,47 proc. \\
\hline $2015-07-27$ & $0,881,26$ proc. & $2,231,56$ proc. & 391,49 proc. \\
\hline
\end{tabular}

2 lentelè. IgE kiekio pacientès J. K. kraujyje kitimas skiriant gydymą omalizumabu

\begin{tabular}{cc}
\hline Data & IgE, kU/l \\
\hline $2014-10-23$ & 187 \\
\hline $2014-11-20$ & 654,6 \\
\hline $2014-12-18$ & 593,9 \\
\hline
\end{tabular}

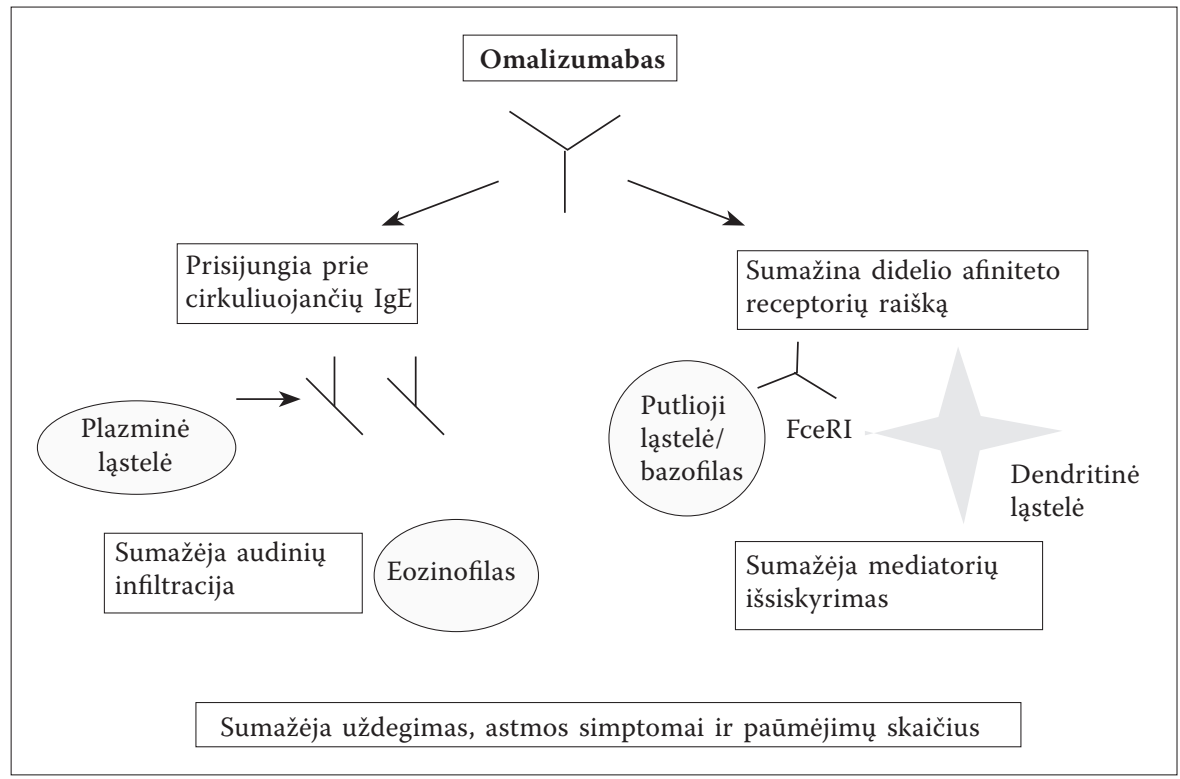

Pav. Omalizumabo veikimo mechanizmas [5]

inhaliuojamụjų gliukokortikoidų dozių (salmeterolio/flutikazono 50/500 $\mu \mathrm{g} 2 \mathrm{k} . / \mathrm{d}$. ir flutikazono $500 \mu \mathrm{g} 2 \mathrm{k} . / \mathrm{d}$.), pacientei dažnai kartojasi astmos simptomai, prasti astmos kontrolès testo rezultatai, rodantys, kad astma nekontroliuojama, auskultuojant visame plaučiu plote girdimi sausi, švilpiantys karkalai, atliktoje spirogramoje - III bronchų obstrukcija, gydytojų konsiliumo metu nuspręsta papildomai skirti gydymą omalizumabu (150 mg 1 k./d. kas 28 dienas po oda, 4 kursai).

Vertinant pacientès būklę po pusès metų pastebèta teigiama astmos dinamika: dusulio epizodai atsiranda tik intensyvaus fizinio krūvio metu, simptomai nakties metu išnyko, sumažèjo trumpai veikiančių beta 2 agonistụ poreikis, sumažèjo inhaliuojamųjų gliukokortokoidu dozė (suminé flutikazono dozè - $1000 \mu \mathrm{g} / \mathrm{d}$.), astmos kontrolès testo rezultatai - iš dalies kontroliuojama astma, astmos paūmèjimu nebuvo, spirogramoje - padidèję forsuoto iškvépimo per pirmąją sekundę tūris $\left(\mathrm{FEV}_{1}\right)$ ir forsuota gyvybinè plaučiu talpa (FVC), palyginti su plaučiu funkcijos rodikliais prieš omalizumabo skyrimą (1 lentelè). tyti pagerèję astmos kontrolės testo rezultatai, sumažejęs ligos paūmèjimų skaičius. Mokslo literatūros duomenimis, omalizumabo efektyvumą rekomenduojama vertinti praejjus 12-16 sav. nuo gydymo pradžios [11]. Klinikinių požymių pokytis, astmos kontrolès testas ir kiti klausimynai, vertinantys gyvenimo kokybę sergant astma, labiausiai atspindi omalizumabo veiksmingumą [6, 8-10]. Kitas svarbus kriterijus suminė gliukokortikoidu dozė (vartojamu astmos kontrolei pasiekti bei paūmejjimui gydyti) [7-11]. Po gydymo omalizumabu šiai pacientei sumažèjo inhaliuojamųjų gliukokortikoidu poreikis

Nors kai kurie tyrimai rodo, kad omalizumabas pagerina plaučių funkcijos rodiklius $[9,10]$, vis dèlto tai nèra svarbiausias šio vaisto efektyvumą įrodantis veiksnys. Be to, skyrus omalizumabo, kai astma jau yra gydoma kitais vaistais, $\mathrm{FEV}_{1}$ dažniausiai nepadideja [11]. Aptariamu klinikiniu atveju pastebèta teigiama plaučiu funkcijos rodikliu dinamika (1 lentelè).

Gydant omalizumabu, IgE koncentracija kraujyje gali padidetti 3-6 kartus, bet tai kliniškai nereikšmingas reiškinys - baigus gydymą iprastai IgE koncentracija sumažeja [11]. Šios pacientės IgE koncentracija kraujyje pradejjus gydymą omalizumabu padidèjo apie 3,5 karto (2 lentelè). Omalizumabo efektyvumui vertinti IgE koncentracijos tyrimai nerekomenduojami, nes vartojant vaistą IgE koncentracija gali ženkliai padidèti.

Omalizumabas yra efektyvus vaistas gydant sunkią persistuojančią alerginę astmą: pagerina ligos kontrolę, padidina kasdienị pacientų aktyvumą, sumažina paūmẻjimų skaičiu ir gliukokortikoidų poreikị. Kai kuriais atvejais vaistas gali pagerinti plaučiu funkcijos rodiklius.

\section{EFFICACY OF OMALIZUMAB IN ASTHMA: CASE REPORT}

\section{LAURA TAMAŠAUSKIENĖ, DIANA BARKAUSKIENÉ, BRIGITA ŠITKAUSKIENE}

Keywords: asthma, omalizumab, anti-lgE.

Summary. Omalizumab - monoclonal antibody against immunoglobulin $E$ - is used as add-on therapy to improve asthma control in patients with severe persistent allergic asthma who have frequent daytime symptoms or night-time awakenings and who have had multiple documented severe asthma exacerbations despite daily high-dose inhaled corticosteroids, plus a long-acting inhaled beta2-agonist. Omalizumab improves asthma control and reduces incidents of exacerbations and doses of steroids. Scientific studies show that this drug is effective as add-on therapy for the treatment of chronic spontaneous urticaria with inadequate response to $\mathrm{H} 1$ antihistamine treatment The aim of this article is to review efficacy of omalizumab for treatment of severe asthma and present case report

\section{LITERATŨRA}

1. Lietuvos pulmonology ir alergology draugija, Lietuvos pulmonology draugija, LSMU, VU. Lietuvos suaugusiuju astmos diagnostikos ir gydymo sutarimas 2015. Kaunas: Vitae Litera, 2015.

2. From the Global Strategy for Asthma Management and Prevention, Global Initiative for Asthma (GINA) 2015. Available from: http:// www.ginasthma.org/

3. Drugs.com. Omalizumab. Availabe at URL: http://www.drugs.com/ppa/omalizumab.html.

4. Stokes JR, Casale TB. The use of anti-IgE therapy beyond allergic asthma. J Allergy Clin Immunol Pract. 2015:3(2):162-6.

5. Pelaia G1, Gallelli L, Renda T, Romeo P, Busceti MT, Grembiale RD, Maselli R, Marsico SA, Vatrella A. Update on optimal use of omalizumab in management of asthma. J Asthma Allergy. 2011; 4:49-59.

6. Zazzali JL, Raimundo KP, Trzaskoma B, Rosén KE, Schatz M. Changes in asthma control, work productivity, and impairment with omalizumab: 5 -year EXCELS study results. Allergy Asthma Proc. 2015; 36(4):283-92.

Literatūros šaltiniai (iš viso 11) redakcijoje. 